\title{
The 16s/23s Ribosomal Spacer Region as a Target for DNA Probes to Identify Eubacteria
}

\author{
Tom Barry, ${ }^{1}$ Gerard Colleran, ${ }^{2}$ Maura Glennon, ${ }^{1}$ \\ L.K. Dunican, 2 and Frank Gannon 1,2 \\ ${ }^{1}$ National Diagnostics Centre, BioResearch Ireland, University College Galway; \\ ${ }^{2}$ The Department of Microbiology, University College Galway, Ireland
}

Variable regions of the $16 \mathrm{~s}$ ribosomal RNA have been frequently used as the target for DNA probes to identify microorganisms. In some situations, however, there is very little sequence variation observed between the 16s rRNA genes of closely related microorganisms. This study presents a general method to obtain species-specific probes using the spacer (intergenic) region between the $16 \mathrm{~s}$ and $23 \mathrm{~s}$ rRNA genes. The overall strategy is analogous to that which has previously been developed for the variable regions of the 16s rRNA genes. Sequence analysis of the 165 rRNA and 23s rRNA coding sequences flanking the spacer regions resulted in the design of PCR primers that can be used to amplify the spacer regions of a wide range of eubacteria. Sequencing the amplified spacer region then gives rise to the information that can be used to select specific DNA sequences for use as a DNA probe or for the generation of specific PCR primers to a microorganism of interest. In this study the approach to develop specific DNA markers for members of the genus Clostridium is described in detall. A specific DNA oligonucleotide probe and PCR primers have been designed for Clostridium perfringens that distinguish it from other organisms in the genus.
The he application of DNA probe methodology to the identification and detection of microorganisms is becoming well established in the field of diagnostic bacteriology. Fundamental to such a technology is the ability to define suitable nucleic acid sequences that identify a particular microorganism or group of related microorganisms. DNA probes have been used successfully in the identification and detection of microorganisms. ${ }^{(1,2)}$ In general, nucleic acid sequences that are used as DNA probe targets for microorganisms fall into five main categories: (1) DNA sequences that code for antigens, (2) DNA sequences that code for toxins, (3) DNA sequences identified by differential hybridization using total DNA probes from related species against a DNA bank made from the microorganism of interest, (4) unique plasmid-borne DNA sequences, and (5) ribosomal RNA (rRNA) sequences.

In the case of the first four categories, the means by which the DNA targets are selected involve laborious cloning methodologies and frequently a signficant amount of biochemical or immunological data. Subsequently, cross-reactivity, nonspecificity, and the possibility of the loss of the target sequences due to recombination and deletion events, especially with relation to plasmid-borne sequences, results, in some cases, in a limited usefulness of these probes. rRNAs in general have been the main targets for the generation of DNA markers for microorganisms, and we have used this region as the target for DNA probes for a number of microorganisms. ${ }^{(2)}$ The major disadvantage these sequences have as candidates for DNA markers is that the "variable" regions can almost be identical when closely related microorganisms are examined, resulting in the need for finely defined stringency conditions when using such probes to detect a microorganism of interest.

In an effort to identify target sequences with greater variability, we have investigated the $16 \mathrm{~s} / 23 \mathrm{~s}$ ribosomal spacer sequences of eubacteria. We argued that the spacer (intergenic) regions should be under minimal selective pressure during evolution and therefore should vary more extensively than sequences within genes that have functional roles. By analogy with the general methodology employed for the analysis of the intragenic 16s rRNA regions, ${ }^{(2,3)}$ a general approach is presented that allows one to establish rapidly the DNA sequence of $16 \mathrm{~s} / 23 \mathrm{~s}$ spacer regions of eubacteria and thereby make a logical choice for the best probe of a given organism.

\section{STRATEGY}

Ribosomes are essential constituents for eukaryotic and prokaryotic cell proliferation and are composed of protein and RNA moities. In eubacteria, the RNA entity comprises of three distinct types: the 16s, 23s, and 5s rRNAs. The genes coding for these rRNAs exhibit an operon organization that is essentially consistent from one eubacterium to another. Briefly, the operon organization consists of a promoter region followed by a se- 
quence coding for the $16 \mathrm{~s}$ rRNA, a spacer or intergenic sequence (which in some instances may contain coding sequences for tRNAs), the 23s rRNA coding sequence, another short spacer sequence, and the sequence coding for 5s rRNA. This arrangement is present in the genome in multicopies, and the number of operons present can vary from one group of microorganisms to another. To date, a number of eubacterial ribosomal operons have been partially or completely sequenced, in addition to over $14416 \mathrm{~s}$ rRNAs and 13 23 s rRNAs. ${ }^{(4,5)}$ Upon examination of the spacer sequences available, we observed that extensive sequence variation existed between microorganisms. It follows that the spacer region should be a good source of species-specific sequences. On the basis of this premise and the sequence data available for $16 \mathrm{~s}$ and $23 \mathrm{~s}$ rRNAs that flank spacer regions, we synthesized oligonucleotide PCR primers that could potentially be used in a general fashion to amplify
$16 s / 23 s$ spacer sequences from a wide range of eubacteria. The $5^{\prime}$ primer, A1, corresponds to a conserved sequence motif from the $3^{\prime}$ end of $16 \mathrm{~s}$ rRNAs (from position 1493 to 1513 of the $16 \mathrm{~s}$ rRNA of E. coli) and the 3' primer, B1, was deduced from an alignment of the $1323 s^{\prime}$ sequences (from position 23 to 43 of the 23s rRNA of $E$. coli) (see Fig. 4). These primers are then used to amplify the spacer regions of the eubacteria of interest; the amplified products are then sequenced and a specific DNA probe or PCR primers can be selected for a particular eubacterium. Figure 1 demonstrates the overall strategy involved.

In this study we have investigated the $16 \mathrm{~s} / 23 \mathrm{~s}$ spacer sequences of a number of species of the genus Clostridium to examine the efficacy of the method. The genus Clostridium encompasses gram-positive anaerobic endosporeforming eubacteria of broad interest to biotechnology, agriculture, and medicine. To illustrate the approach, we

Ribosomal Operon

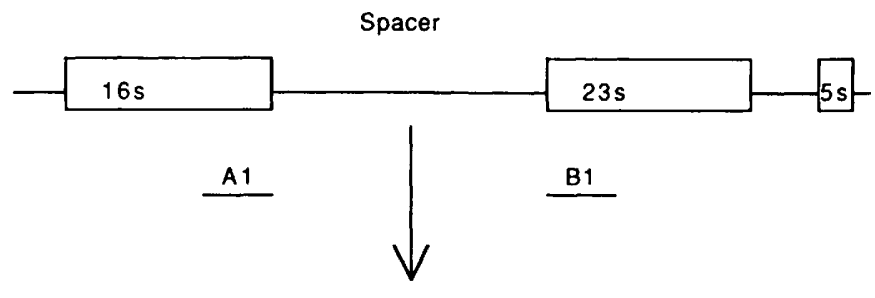

PCR

Amplification

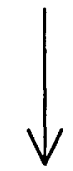

Sequence and

Homology Aligments.

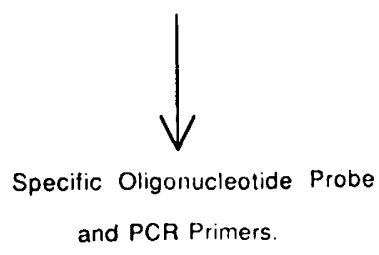

FIGURE 1 Schematic representation of the regime used for developing 16s/23s spacer regionspecific oligonucleotide DNA probes and PCR primers for eubacteria.

have developed a specific DNA oligonucleotide probe and specific oligonucleotide primers for use in a PCR assay to detect and distinguish Clostridium perfringens, a human pathogen, from other clostridia in the genus.

\section{EXPERIMENTAL PROTOCOL}

\section{Enzymes and Reagents}

Restriction endonuclease SmaI, T4 ligase, T4 polynucleotide kinase, and Taq DNA polymerase were purchased from Promega. M13mp11 DNA, proteinase $\mathrm{K}$, RNase, dNTPs, and pBR HaellI size markers were purchased from Boehringer-Mannheim. T7 polymerase and sequencing reaction mixes were purchased from Pharmacia. Nytran was purchased from Schleicher \& Schuell. NuSieve agarose gel was purchased from FMC Bioproducts. $\left[\gamma^{32} \mathrm{P}\right] \mathrm{dATP}$ was purchased from Amersham International.

\section{Oligonucleotides}

Single-strand oligonucleotides (all 20mers) were synthesized on an Applied Biosystems automated synthesizer. After deblocking and ethanol precipitation/washing, no further purification of the oligonucleotides was required prior to use as an oligonucleotide probe or as PCR primers.

\section{Preparation of Total Cenomic DNA} from Clostridium spp. and $B$. subtilus

Total genomic DNA was prepared as follows: $250 \mathrm{ml}$ of clostridial cultures were grown anaerobically at $37^{\circ} \mathrm{C}$ without agitation in reinforced clostridial medium overnight. The cultures were then harvested by centrifugation at $7000 \mathrm{rpm}$ in a Sorvall GSA rotor at $4^{\circ} \mathrm{C}$ for $10 \mathrm{~min}$. The supernatants were removed and the pellets were resuspended in $2 \mathrm{ml}$ of sterile deionized water. Then, $8 \mathrm{ml}$ of ice-cold absolute acetone was added to the cellular emulsion and mixed vigorously, and the cells were kept on ice for 30 min. The cells were once again harvested as above and the resultant pellet was allowed to dry under vacuum for $20 \mathrm{~min}$. The cell pellets were then resuspended in $5 \mathrm{ml}$ of $0.1 \mathrm{M}$ Tris- $\mathrm{HCl}$ (pH 8.0$)$, lysozyme $(10 \mathrm{mg} / \mathrm{ml}$, final concentration), incubated at $37^{\circ} \mathrm{C}$ for $4 \mathrm{hr}$ under continuous agitation, and then harvested as above. The pellet was 
resuspended in $5 \mathrm{ml}$ of sterile water containing $2 \mathrm{mg} / \mathrm{ml}$ proteinase $\mathrm{K}$ and incubated at $4^{\circ} \mathrm{C}$ overnight, followed by an incubation at $37^{\circ} \mathrm{C}$ for $1 \mathrm{hr}$. One milliliter of $20 \%$ SDS and $20 \mu \mathrm{l}$ of diethylpyrocarbonate (a nuclease inhibitor) were then added and the suspension was allowed to stand at $37^{\circ} \mathrm{C}$ for a further $15 \mathrm{~min}$. Six milliliters of Tris-HCl-saturated phenol $(\mathrm{pH}$ 8.0) was added to the suspension and then centrifuged, and the aqueous phase was removed and extracted again with phenol. A subsequent extraction of the aqueous phase with $1 / 2$ volume phenol, 1/2 volume chloroform/ isoamyl alcohol (24:1) was then carried out, the aqueous phase was removed, and six volumes of absolute ethanol added. Total genomic DNA was spooled out with a sterile glass rod, allowed to air-dry, and then resuspended in 1 $\mathrm{ml}$ of sterile deionized water containing RNase $(10 \mu \mathrm{g} / \mathrm{ml})$.

\section{PCR Amplification of the 16s/23s Spacer Sequences}

PCR amplifications were routinely carried out in a $100-\mu$ l reaction volume which consisted of: $100 \mathrm{ng}$ of clostridial total genomic DNA equivalent to $10^{5}$ bacterial cells, $100 \mathrm{ng}$ of each of the primers A1/B1 (Fig. 3), $20 \mathrm{~mm}$ $\mathrm{NaCl}, 50 \mathrm{~mm}$ Tris (pH 9), 1\% Triton X$100,0.1 \%$ gelatin, $4 \mathrm{~mm} \mathrm{MgCl}_{2}, 200$ $\mu \mathrm{M}$ of each of the four dNTPs, and 2.5 units of Taq DNA polymerase. Where PCR amplification was carried out directly from culture, the bacterial cells $\left(10^{6}\right.$ or less) were initially heated to $95^{\circ} \mathrm{C}$ for $5 \mathrm{~min}$, followed by an incubation at $55^{\circ} \mathrm{C}$ with proteinase $\mathrm{K}(10$ $\mu \mathrm{g} / \mathrm{ml}$ ) for $5 \mathrm{~min}$ and ending with an incubation at $95^{\circ} \mathrm{C}$ for $10 \mathrm{~min}$ to denature the proteinase $\mathrm{K}^{(2)}$ At this point Taq DNA polymerase was then added. PCR amplifications were carried out for $30 \mathrm{sec}$ denaturation at $94^{\circ} \mathrm{C}, 30 \mathrm{sec}$ annealing at temperatures ranging from $40^{\circ} \mathrm{C}$ to $55^{\circ} \mathrm{C}$ (the annealing temperature of the primers varied for each eubacteria such that background of nonspecific amplified products was eliminated; these values are given in parentheses in Figs. 2 and 3) and an extension time of $30 \mathrm{sec}$ at $72^{\circ} \mathrm{C}$. Thirty cycles were carried out in a PerkinElmer Cetus Thermocycler. The degree and the specificity of amplification were analyzed by gel electrophoresis on $3 \%$ NuSieve agarose minigels. Approximately $50 \mu$ l of each PCR reaction was then used for the purposes of cloning into the SmaI site of M13mp11.(2) Single-stranded DNA was prepared from recombinants for dideoxy sequencing using $\mathrm{T} 7$ polymerase.

\section{PCR Amplification Using the C. perfringens-Specific Primers}

PCR reactions, using specific primers $\mathrm{C} 1 / \mathrm{C} 2$ (these sequences are underlined in Fig. 3), were carried out as above, except that the primers had an optimum $\mathrm{MgCl}_{2}$ final concentration of 3 $\mathrm{mM}$ and an optimal annealing temperature of $45^{\circ} \mathrm{C}$.

\section{Radioactive Probe Preparation and Hybridization Conditions}

One hundred nanograms of the 20-mer DNA probe were end-labeled with $[\gamma$ ${ }^{32}$ P]ATP by the recommended procedures using $\mathrm{T} 4$ polynucleotide kinase. PCR products were transferred to Nytran using the protocol outlined by the manufacturers. Prehybridization was carried out in $100-\mathrm{ml}$ solution containing $6 x$ SSC, 10x Denhardts, and $0.1 \%$ SDS for $1 \mathrm{hr}$ at $65^{\circ} \mathrm{C}$. The prehybridization solution was removed and a hybridization solution $(8 \mathrm{ml})$ consisting of $5 \times$ SSPE and $0.1 \%$ SDS was added. Hybridization was carried out for $1 \mathrm{hr}$ at $50^{\circ} \mathrm{C}$. The membranes were then washed two times in $100 \mathrm{ml}$ of $6 \mathrm{xSC}, 0.1 \%$ SDS for $10 \mathrm{~min}$ at room temperature, followed by a final stringent wash of a $100-\mathrm{ml}$ solution consisting of $2 \times$ SSC, $0.1 \%$ SDS at hybridization temperature $\left(50^{\circ} \mathrm{C}\right)$ for $30 \mathrm{~min}$. The membranes were then exposed to X-ray film and autoradiography was carried out for up to $5 \mathrm{hr}$ at $-80^{\circ} \mathrm{C}$.

\section{RESULTS}

\section{The Generation of a Specific DNA Probe and PCR Primers for Clostridium perfringens}

Initially, primers A1 and B1 were used successfully to amplify a broad range of both gram-positive and gramnegative eubacteria $16 \mathrm{~s} / 23 \mathrm{~s}$ spacer regions using the PCR. The results obtained from the gel electrophoresis pattern of the amplified products show the extent of sequence variation that exists between eubacterial spacer regions, as fragment mobility for each
TABLE 1 Bacterial Strains Used in This Study

\begin{tabular}{lr}
\hline 1. Micrococcus luteus & ATCC. 9278 \\
2. Corynebacterium diphtheriae ATCC. 27010 \\
3. Serratia marcescens & ATCC.13880 \\
4. Mycobacterium tuberculosis & ATCC. 9360 \\
5. Enterococcus faecalis & ATCC.19433 \\
6. Pseudomonas aeruginosa & ATCC. 19582 \\
7. Bacillus subtilis & ATCC. 6051 \\
8. Clostridium beijerinckii & NCDO. 1759 \\
9. Clostridium buryricum & DSM. 552 \\
10. Clostridium difficile & ATCC. 9689 \\
11. Clostridium glycolicum & NCDO. 1791 \\
12. Clostridium pasteurianum & DSM. 525 \\
13. Clostridium perfringens & ATCC. 13124 \\
14. Clostridium sporogenes & NCIB. 532 \\
15. Clostridium tyrobutyricum & DSM. 663 \\
16. Clostridium barkeri & ATCC. 25843 \\
17. Clostridium nexile & DSM. 1787 \\
\hline
\end{tabular}

amplified product varied greatly, with a size range of 250 to $600 \mathrm{bp}$ (Table 1; Fig. 2). In an effort to determine whether such sequence variation was observed between closely related eubacteria, PCR amplification of the

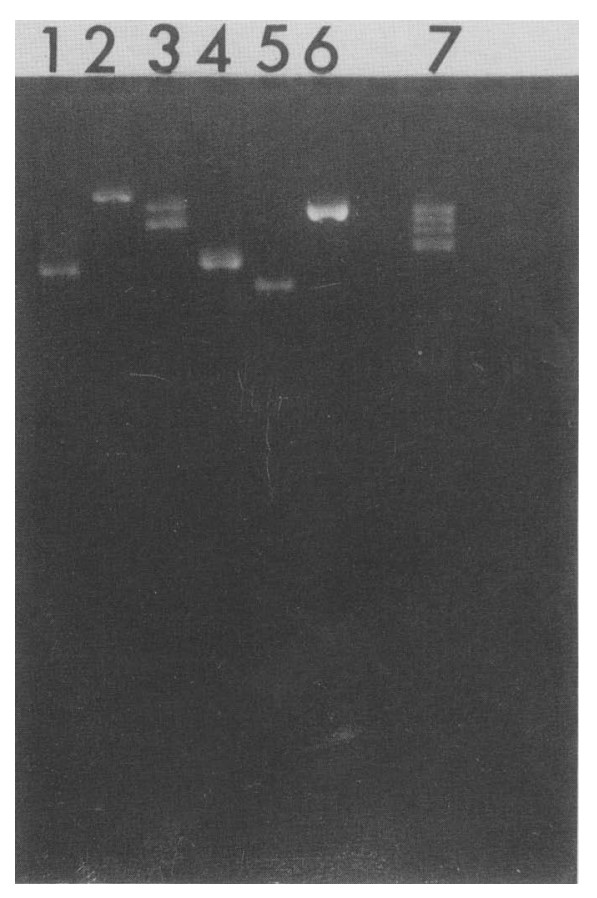

FICURE 2 Gel electrophoresis of PCRamplified $16 \mathrm{~s} / 23 \mathrm{~s}$ intergenic spacer regions from a range of eubacteria using general primers $\mathrm{A} 1 / \mathrm{B} 1$. (Lane 1) $\mathrm{M}$. luteus $\left(50^{\circ} \mathrm{C}\right)$; (lane 2) $C$. diphtheriae $\left(45^{\circ} \mathrm{C}\right.$ ); (lane 3) $S$. marcesens $\left(55^{\circ} \mathrm{C}\right)$; (lane 4) M. tuberculosis $\left(45^{\circ} \mathrm{C}\right.$ ); (lane 5) E. faecalis $\left(50^{\circ} \mathrm{C}\right.$ ); (lane 6 ) $P$. aeroguinosa $\left(55^{\circ} \mathrm{C}\right)$; (lane 7 ) pBR322 Haell size markers. Optimum annealing temperatures of primers are given in parentheses. 


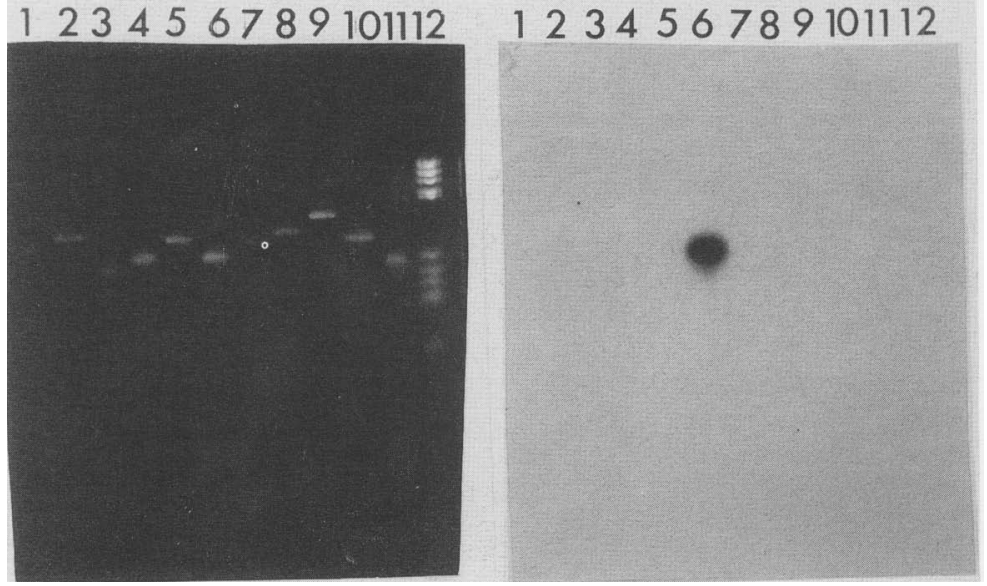

FICURE 3 (Left) Gel electrophoresis (3\% NuSieve) of amplified products generated from A1/B1-primed PCR reactions of C. beijerinckii $\left(45^{\circ} \mathrm{C}\right.$ ) (lane 1 ); C. butyricum $\left(45^{\circ} \mathrm{C}\right.$ ) (lane 2 ); C. difficile $\left(40^{\circ} \mathrm{C}\right)$ (lane 3); C. glycolicum $\left(40^{\circ} \mathrm{C}\right)$ (lane 4); C. pasteurianum $\left(50^{\circ} \mathrm{C}\right)$ (lane 5); C. perfringens $\left(45^{\circ} \mathrm{C}\right)$ (lane 6); C. sporogenes $\left(40^{\circ} \mathrm{C}\right)$ (lane 7$) ; C$. tyrobutyricum $\left(40^{\circ} \mathrm{C}\right.$ ) (lane 8 ); $\mathrm{C}$. barkeri $\left(55^{\circ} \mathrm{C}\right)\left(\right.$ lane 9); C. nexile $\left(45^{\circ} \mathrm{C}\right)$ (lane 10$) ; B$. subtilis $\left(45^{\circ} \mathrm{C}\right)$ (lane 11$)$; pBR HaellI size markers (lane 12). Optimum annealing temperatures for each microorganism with primers A1/B1 are given in parentheses. (Right) Corresponding Southern blot demonstrating the specificity of the $C$. perfringens oligonucleotide probe (see Fig. 4).

spacer region of 10 clostridia (Table 1) and the phylogenetically related Bacillus subtilis was performed using these primers. Again, significant size differences are found (Fig. 3), implying sequence variation. The DNA sequences amplified from three clostridial species were determined. Alignment of these sequences required the introduction of multiple gaps to maximize the homology, which in any case was low, and many opportunities are thus presented in the choice of speciesspecific probes (Fig. 4). ${ }^{(6)}$ A DNA probe was selected for $C$. perfringens (underlined in Fig. 4) on the basis of these data and this was tested against the original panel of amplified clostridia 16s/23s spacer sequences. Only C. perfringens was detected with this oligonucleotide probe (Fig. 3b) under moderate stringency conditions. The DNA sequence in Figure 4 also allows one to select species-specific primers for selective PCR amplification. When these were chosen for $C$. perfringens and tested against the panel of clostridia, only $C$. perfringens was amplified, as judged by visualization with ethidium bromide staining of DNA following gel electrophoresis (Fig. 5). In a final demonstration of the application of this technique, six clinical isolates that had been identified as $C$. perfringens using standard microbiological tests were amplified with the species-specific primers. One sample failed to yield a visible band (Fig. 6A). When the general primers (A1 and $\mathrm{B} 1$ ) were used, a DNA fragment of a size greater than the control and the other C. perfringens amplified fragments was obtained for this sample (Fig. 6B). The results suggested that this isolate was not $C$. perfringens. A final indication that this isolate was not $C$. perfringens comes from the fact that all the other samples hybridized with the $C$. perfringens oligonucleotide probe following amplification (Fig. 6C), whereas it did not.

\section{Analysis of Multiple Copies of the C. perfringens 16s/23s Spacer Sequence}

It is known that $C$. perfringens contains nine copies of the ribosomal operon. ${ }^{(7)}$ In an effort to address the question of whether sequence variation between the $16 \mathrm{~s} / 23 \mathrm{~s}$ spacer regions of each of these operons existed and if tRNA coding sequences were present, we sequenced 12 independent $C$. perfringens M13 clones derived from fragments amplified by PCR using the general primers.

Six of these recombinants were shown to have identical sequences, four were shown to exhibit one or more point substitutions, concentrated predominantly at the $3^{\prime}$ end of the PCR products, and two were shown to contain deletions, 20 and 56 bases, respectively, also at the $3^{\prime}$ end of the PCR products. Each substitution or set of substitutions was unique to a single PCR product, indicating that such sequence alterations were random events and are presumably due to "errors" of

$$
\begin{aligned}
& \text { Al: 5' agtcGtaacaagctaagccG }{ }^{3} \\
& \text { B1: }{ }^{\circ}{ }_{C} \mathrm{~T} / \mathrm{C} \text { A/G T/C TGCCAACCATCCACT }{ }^{3} \text {, }
\end{aligned}
$$

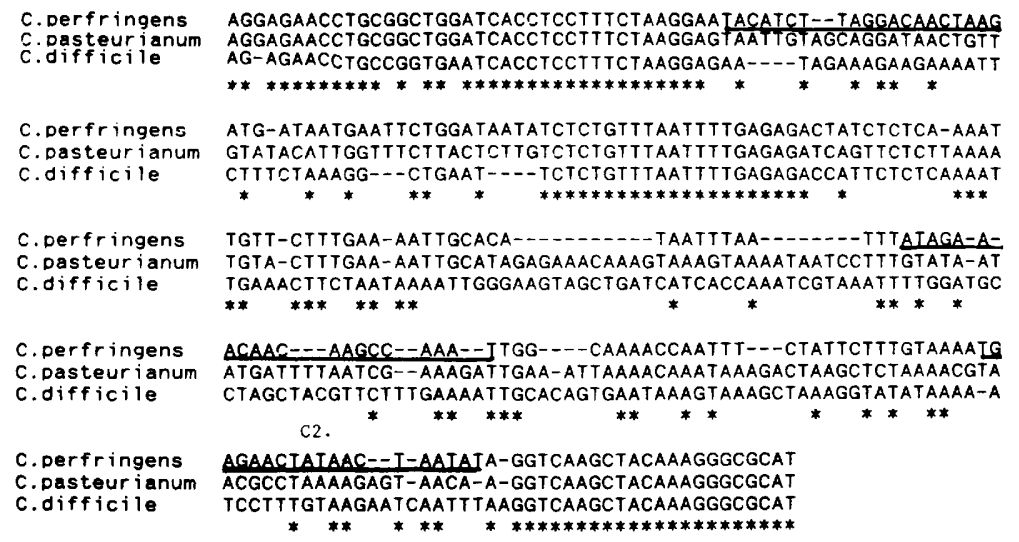

FIGURE 4 Multiple sequence alignment of the 16s/23s spacer region of $C$. perfringens, $C$. pasteurianum, and $C$. difficle. The specific $C$. perfringens oligonucleotide probe is underlined, as are the specific primers $\mathrm{C} 1 / \mathrm{C} 2$. The sequences of $C$. pasteurianum and $C$. difficle were obtained from 10 different M13 isolates. Where random base point alterations were noted the most frequently occurring base is reported. 


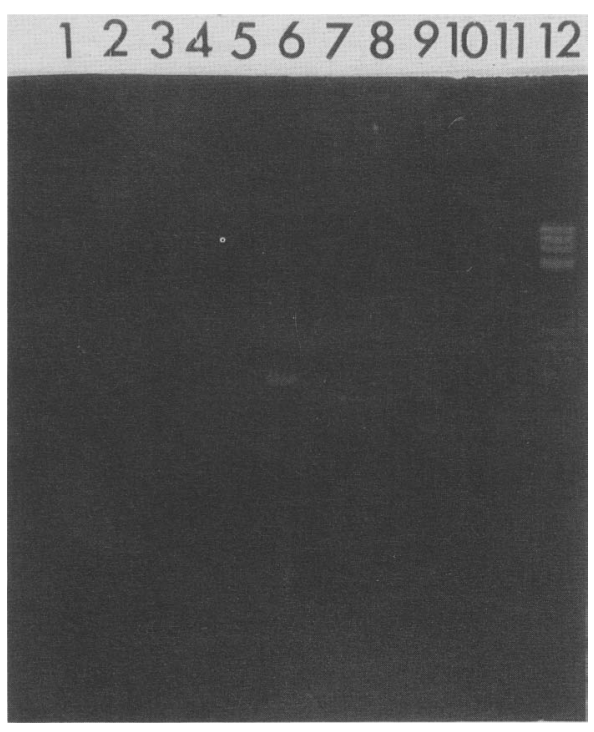

FIGURE 5 Specificity of PCR amplification with $C$. perfringens spacer primers $\mathrm{C} 1 / \mathrm{C} 2$. These primers were assayed against the panel of clostridia used in this study. (Lane 1) C. heijerinckii; (lane 2) C. butyricum; (lane 3) C. difficle; (lane 4) C. glycolicum; (lane 5) C. pasteurianum; (lane 6) C. perfringens; (lane 7) C. sporogenes; (lane 8) C. tyrobutyricum; (lane 9) C. barkeri; (lane 10) C. nexile; (lane 11) B. subtilis; (lane 12) pBR322 HaellI size markers.

PCR amplification. Recently, similar observations have been published in more detail ${ }^{(8)}$ and our results are consistent with the error type and error rate of PCR amplification obtained. It is suggested that there is a requirement to sequence at least eight to ten independent PCR products, with three to four of these products having identical sequences, such that an overall correct consensus sequence can be determined. ${ }^{(8)}$

From this analysis we have concluded that the $16 \mathrm{~s} / 23 \mathrm{~s}$ spacer region of each of the nine operons of $C$. perfringens is very similar in sequence. Furthermore, no tRNA sequences were evident with these sequences. This suggests that within a microorganism there is strong pressure for this potentially hypervariable region to remain constant.

Preliminary evidence to suggest that tRNA sequences may be present in $S$. marcesens $16 \mathrm{~s} / 23 \mathrm{~s}$ spacer sequences is given in Figure 2 (lane 3), as two PCR products are observed upon amplification with the general primers A1/B1. These amplified products differ by ap- proximately $80 \mathrm{bp}$ in length, which would correspond to the presence of at least one tRNA sequence in the intergenic regions of some of the $16 \mathrm{~s} / 23 \mathrm{~s}$ operons of this microorganism.

\section{DISCUSSION}

In an earlier study, we outlined a general method that can be used to develop DNA probes for microorganisms. ${ }^{(2)}$ In its original presentation, the strategy was shown to work effectively, focusing on the variable $\mathrm{V} 6$ region of $16 s$ rRNA. However within closely related organisms (e.g., Mycobacteria species) this "variable" region is quite invariant and therefore is not a suitable target for the generation of DNA probes. ${ }^{(9)}$ We have, as a result, sought to identify more hypervariable regions using the strategy originally developed for the 16s rRNA variable intragenic regions. Using this methodology, we have demonstrated that very significant sequence heterogeneity exists within the eubacterial $16 \mathrm{~s} / 23 \mathrm{~s}$ spacer region at the genus and species levels. In a similar approach recently reported, the corresponding spacer region of closely related symbiotic fungi suggests that the degree of heterogeneity in these genera is not very marked.(10) However, further studies that would provide data on this region of a greater sample of fungi would be required to clarify this matter.

Given the high degree of sequence variation observed from one species to another, one concern was that the spacer region might alter significantly between different strains of a species. In a limited experiment, we tested our specific oligonucleotide probe and PCR primers against a panel of six different clinical isolates of $C$. perfringens. This microorganism causes a number of pathological conditions of man and animals that can be broadly defined as necrotic diseases (i.e., gas gangrene) and enterotoxemias (i.e., foodpoisoning syndromes). The clinical samples that were used to validate this probe were all presumptive $C$. perfringens on the basis of their properties in standard clinical microbiological tests. Five of the isolates were confirmed as being $C$. perfringens on the basis of the successful use of the specific probe and primers that had been developed in the course of this study from data obtained from the $C$. perfringens ATCC 13124 typed strain. This gives some indication that these sequences are conserved from one strain to another; however, a more extensive study is required to validate such observations. The clinical isolate, which was not detected by the specific DNA probe/specific PCR primers, was reevaluated by carrying out three phenotypic tests to determine whether this isolate was in fact a $C$. perfringens. Upon reassessment, this microorganism was unable to hydrolyze $10 \%$ gelatin, did not liquify esculin, and was a faculative anaerobe. ${ }^{(11)}$ Consequently this culture, in fact, was not

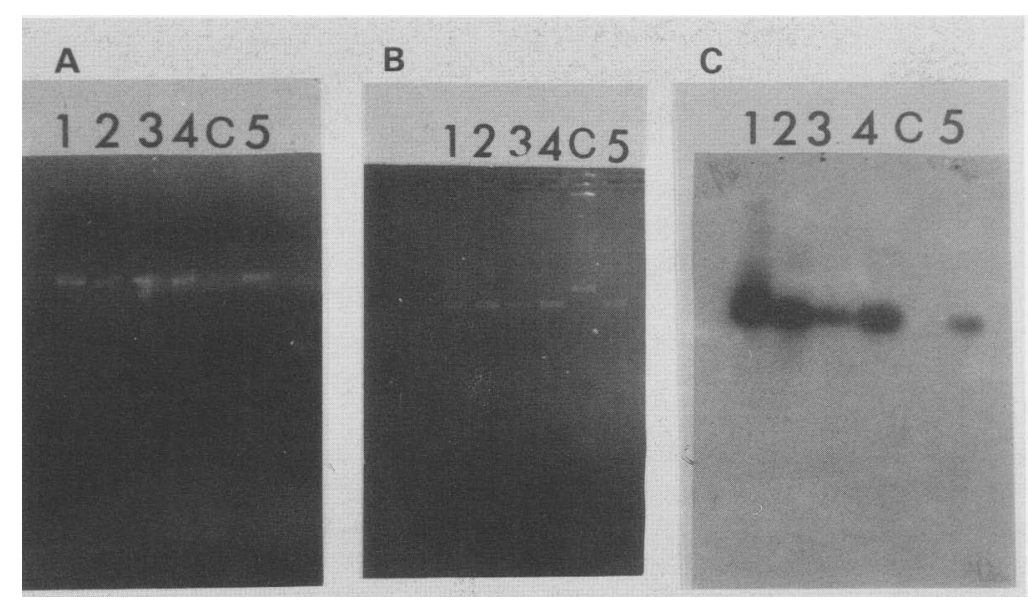

FIGURE 6 (A) PCR amplification of six clinical isolates, identified as C. perfringens, using specific primers $\mathrm{C} 1 / \mathrm{C} 2$. (B) Subsequent PCR amplification of the six clinical isolates using general primers A1/B1. (C) Corresponding Southern blot using the $C$. perfringens-specific probe. 
C. perfringens and was considered to have arisen from process contamination.

The overall strategy used in this and the previous study ${ }^{(2)}$ has the advantage of providing specific DNA probes for each microorganism from the panel of organisms tested. For example the data shown in Figure 4 of this study allow for the generation of DNA probes/PCR primers for $C$. pasteurianum and for $D$. difficle. The latter, like $C$. perfringens, is a human pathogen. ${ }^{(12)}$ This list of probes can be rapidly expanded to other microorganisms using the same rationale. Furthermore, the rapid technique presented requires no previous information of the molecular biology of the microorganism of interest. In conclusion, the use of DNA sequences in the spacer region between the $16 \mathrm{~s}$ and $23 \mathrm{~s}$ RNA shows that an efficient and specific DNA probe can be generated that can distinguish readily between closely related eubacteria.

\section{ACKNOWLEDGMENTS}

We thank Prof. J. Flynn and Dr. M. Cormican, Department of Bacteriology, University College Hospital, Galway, for clinical isolates and Dr. R. Powell for helpful discussion. This work was supported in part by the Health Research Board, Ireland.

\section{REFERENCES}

1. Macario, A.J.L. and E.C. de Macario. 1990. Gene probes for bacteria. Academic Press,

2. Barry T., R. Powell, and F. Gannon. 1990. A general method to generate DNA probes for microorganisms. BioTechnology 8: 233-236.

3. Saiki, R.K., D.H. Gelfand, S. Stoffel, S.J. Scharf, R. Higuchi, G.T. Horn, K.B. Mullis, and H.A. Erlich. 1988. Primer directed enzymatic amplification of DNA with a thermostable DNA polymerase. Science 239: 487-491

4. Srivastava, A.K. and D. Schlessinger. 1990. Mechanism and regulation of bacterial ribosomal RNA processing. Annu. Rev. Microbiol. 44: 105-129.

5. Sequences supplement. 1990. Nucleic Acids Res. 18.

6. Higgins, D.G. and P.M. Sharp. 1988. Clustal: A package for performing multiple sequence alignment on a microcomputer. Gene 73: 237-244.

7. Canard, B. and S.T. Coles. 1989. Genome organisation of the anaerobic pathogen $C$. perfringens. Proc. Natl. Acad. Sci. 86: 6676-6680.

8. Ennis, P.D., J. Zemmour, R.D. Slater, and P. Parham. 1990. Rapid cloning of HLA-A,B CDNA by using the polymerase chain reaction: Frequency and nature of errors produced in amplification. Proc. Natl. Acad. Sci. 87: 2833-2837.

9. Rogall, T., J. Wolters, T. Flohr, and E.C. Bottger. 1990. Towards a phylogeny and definition of species at the molecular level within the genus Mycobacterium. Int. J. Syst. Bacteriol. 40: 323-330.

10. Gardes, M., T.J. White, J.A. Fortin, T.D. Burns, and J.W. Taylor. 1991. Identification of indigenous and introduced symbiotic fungi in ectomycorrhizae of nuclear and mitochondrial ribosomal DNA. Can. J. Bot. 69: 180-190.

11. Cato, E.P., W.L. George, and S.M. Finegold. 1986. The genus Clostridia. In Bergey's manual of systematic bacteriology (eds. P.H.A. Sneath, N.S. Mair, M.E. Sharpe, and J.G. Holt), pp. 1141-1200. Williams and Wilkins, Baltimore.

12. Minton, N.P. and D.J. Clarke. 1989. Clostridia. Biotechology handbooks 3. Plenum Press, New York and London.

Received May 20, 1991; accepted in revised form Iune 25, 1991. 


\section{ERRATUM}

Barany, F. 1991. The ligase chain reaction in a PCR world. PCR Methods Applic. 1:5-16.

Table 1 of the above titled paper inadvertently listed an incorrect value for NAD in Method 1; the correct value is $1 \mathrm{mM}$, not $10 \mathrm{mM}$ as stated. The correct version of Method 1 is reproduced on this page.

\section{ERRATUM}

Barry, T., G. Colleran, M. Glennon, L.K. Dunican, and F. Gannon. 1991. The $16 \mathrm{~s} / 23$ s ribosomal spacer region as a target for DNA probes to identify eubacteria. PCR Methods Applic. 1:51-62.

Figure 4 has errors in the $A 1$ and $B 1$ primers. The correct primers are:

A1 5'-AGTCGTAACAAGGTAGCCG-3 ' B1 $5^{\prime}-\mathrm{C}$ T/C A/G T/C TGCCAAGGCAT CCACC $-3^{\prime}$
TABLE 1 Ligase Chain Reaction Methods

\begin{tabular}{|c|c|}
\hline & Method $1^{\mathrm{a}}$ \\
\hline Target DNA & $\beta^{A}, \beta^{S}$ \\
\hline Standard detection & $\begin{array}{l}1-10 \text { attomoles }\left(6 \times 10^{5}\right. \\
\left.\text { to } 6 \times 10^{6} \text { molecules }\right)\end{array}$ \\
\hline $\begin{array}{l}\text { Signal-to-noise } \\
\text { no target under } \\
\text { standard conditions }\end{array}$ & 1700 to $>2000^{b}$ \\
\hline $\begin{array}{l}\text { single-base mismatch } \\
\text { under standard conditions }\end{array}$ & 75 to $>500^{b}$ \\
\hline Lowest detection & 200 molecules \\
\hline $\begin{array}{l}\text { Position of } \\
\text { discriminating } \\
\text { nucleotide }\end{array}$ & $\begin{array}{l}3^{\prime} \text { base of both } \\
\text { strands (single- } \\
\text { base } 3^{\prime} \text { overhang) }\end{array}$ \\
\hline $\begin{array}{l}T_{m} \text { discrimination } \\
\text { oligonucleotides }\end{array}$ & $\begin{array}{l}64^{\circ} \mathrm{C}-68^{\circ} \mathrm{C} \\
\text { (23- to } 28 \text {-mers) }\end{array}$ \\
\hline $\begin{array}{l}\mathrm{T}_{\mathrm{m}} \text { adjacent } \\
\text { oligonucleotides }\end{array}$ & $\begin{array}{l}70^{\circ} \mathrm{C} \\
(22 \text {-mers) }\end{array}$ \\
\hline $\begin{array}{l}\text { Amount of each } \\
\text { oligonucleotide }\end{array}$ & $\begin{array}{l}40 \text { femtomoles } \\
(0.28 \mathrm{ng})\end{array}$ \\
\hline Volume & $10 \mu \mathrm{l}$ \\
\hline Buffer conditions & $\begin{array}{l}20 \mathrm{mM} \text { Tris- } \mathrm{HCl}, \mathrm{pH} 7.6^{\mathrm{c}} \\
100 \mathrm{mM} \text { or } 150 \mathrm{mM} \mathrm{KCl} \\
10 \mathrm{mM} \mathrm{MgCl}_{2} \\
10 \mathrm{mM} \mathrm{DTT}^{+} \\
1 \mathrm{mM} \mathrm{NAD}^{+} \\
1 \mathrm{mM} \text { EDTA }\end{array}$ \\
\hline $\begin{array}{l}\text { Carrier DNA to } \\
\text { suppress background }\end{array}$ & $4 \mu \mathrm{g}$ of salmon sperm DNA \\
\hline $\begin{array}{l}\text { Additional features } \\
\text { for suppression of } \\
\text { target independent } \\
\text { background }\end{array}$ & $\begin{array}{l}5 \text { ' phosphate on adjacent } \\
\text { oligonucleotides only; } \\
\text { noncomplementary tails on } \\
\text { outside of oligonucleotides; } \\
\text { single-base } 3 \text { ' overhang on } \\
\text { discriminating oligonucleotides }\end{array}$ \\
\hline Thermostable enzyme & 15 nick-closing units ${ }^{d}$ \\
\hline \multirow[t]{3}{*}{ Cycle conditions } & $\begin{array}{l}94^{\circ} \mathrm{C}, 1 \mathrm{~min} \\
65^{\circ} \mathrm{C}, 4 \mathrm{~min} \\
20 \text { or } 30 \text { cycles }\end{array}$ \\
\hline & or \\
\hline & $\begin{array}{l}94^{\circ} \mathrm{C}, 0.5 \mathrm{~min} \\
65^{\circ} \mathrm{C}, 2 \mathrm{~min} \\
30 \text { or } 40 \text { cycles }\end{array}$ \\
\hline
\end{tabular}




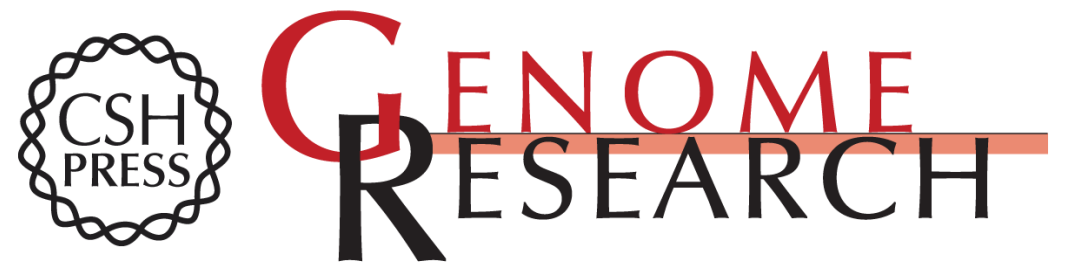

\section{The 16s/23s ribosomal spacer region as a target for DNA probes to identify eubacteria.}

T Barry, G Colleran, M Glennon, et al.

Genome Res. 1991 1: 51-56

Access the most recent version at doi:10.1101/gr.1.1.51
Related Content The 16s/23s ribosomal spacer region as a target for DNA probes to identify eubacteria
T. Barry, G. Colleran, F. Glennon, et al.
Genome Res. November, 1991 1: 149
References This article cites 8 articles, 3 of which can be accessed free at: http://genome.cshlp.org/content/1/1/51.full.html\#ref-list-1
Articles cited in:
http://genome.cshlp.org/content/1/1/51\#related-urls

\section{License}
Email Alerting Receive free email alerts when new articles cite this article - sign up in the box at the Service top right corner of the article or click here.

\section{Affordable, Accurate Sequencing.}

To subscribe to Genome Research go to:

https://genome.cshlp.org/subscriptions 